\title{
IMPACT OF CLIMATE CHANGE ON OIL FATTY ACID COMPOSITION OF PEANUT (Arachis hypogaea L.) IN THREE MARKET CLASSES
}

\author{
Fadul Onemli ${ }^{*}$
}

Peanut (Arachis hypogaea L.) is one of the most important oilseed crops of the world. The fatty acid composition plays an important role in oil quality. Experiments were performed to examine the variation in oil fatty acids of three normal oleic peanut market types (Virginia, Valencia, and Spanish) in 2008, 2009, and 2010. Variations of botanical variety, year and their interaction were highly significant for oil content and all 13 fatty acids studied. Oil content in different peanut market types exhibited significant differences. The maximum oil content (51.993\%) was found in Virginia (NC-7), while Valencia (New Mexico Valencia A) accumulated the minimum oil content (47.197\%). Virginia had also the highest oleic acid percentage. Higher temperatures during seed development in 2010 resulted in greater oleic contents than 2008 and 2009 while lower temperatures post anthesis in 2009 caused higher linoleic acid. It was observed different effects of years in oil fatty acid composition according to peanut types. The highest percentages of linoleic acid for Virginia, Valencia, and Spanish were observed in 2010, 2008, and 2009, respectively. The highest negative correlation was noted for oleic and linoleic acids (r: -0.985). Oleic acid was also correlated negatively with arachidic and behenic acids.

Key words: Arachis hypogaea subsp. fastigiata, temperature, correlation.

$\mathrm{T}$ he peanut (Arachis hypogaea L.) is known by several names throughout the world, such as groundnut and earth nut. The peanut plant is unusual because it flowers above ground and pods containing one to five seeds are produced underground. It seeds are rich source of edible oils, and is fifth most important oilseed in the world.

The peanut is a member of the genus Arachis, subtribe Stylosanthinae, tribe Dalbergieae of family Fabaceae. Arachis hypogaea is an annual herb of indeterminate growth habit, which has been divided into the two subspecies, hypogaea and fastigiata, each with several botanical varieties. Subspecific and varietal classifications are mostly based on location of flowers on the plant, patterns of reproductive nodes on branches, numbers of trichomes, and pod morphology. Peanut production and marketing have resulted in designation of four market classes which generally correspond to subspecific and varietal groups as follows: Runner (subsp. hypogaea var. hypogaea - var. hirsuta: Peruvian Runner), Virginia (subsp. hypogaea var. hypogaea), Spanish (subsp. fastigiata var. vulgaris), and Valencia (subsp. fastigiata var.fastigiata) (Stalker, 1997; Tillman and Stalker, 2009).

Oil content of peanut varies from $40 \%$ to $60 \%$ depend on market types and years. Peanut oil varies both in quantity and relative proportion of fatty acids. The fatty acid composition plays an important role in determining shelf life, nutrition, and flavor of peanut. Since fatty acids

${ }^{1}$ University of Namik Kemal, Faculty of Agriculture, 59030 Tekirdag, Turkey. "Corresponding author (fonemli@nku.edu.tr).

Received: 27 March 2012.

Accepted: 29 August 2012. make up the major portion of weight of an oil molecule, physical and chemical properties of the oil tend to be determined by properties of the predominant fatty acids (Aruna and Nigam, 2009).

Modification of fatty acid composition has been a major goal of breeding programs. Main factors that influence oil and other composition components of peanut include variety and environmental production conditions such as light, temperature, water stress, and atmospheric constituents (Pattee, 2005). Oil content and fatty acid composition of peanut have been studied in different cultivars and different environments (Berry, 1982; Hinds, 1995; Dwivedi et al., 1996; Anderson et al., 1998; Golombek et al., 2001; Reddy et al., 2003; Hassan et al., 2005; Asibuo et al., 2008; Nadaf et al., 2009). But there is limited literature about climatic effects on fatty acid composition in differing botanical peanut types.

Knowing better combination effects of climatic fluctuations and botanical types on fatty acid composition would be useful in designing management practices to obtain a specific oil quality and in improving predictions of crop models. The main objective of this work was to investigate the effects of growing years in three different market types (Virginia, Spanish, and Valencia) on fatty acid composition of peanut oil.

\section{MATERIALS AND METHODS}

\section{Crop varieties}

In this research, normal oleic cultivars NC-7, New Mexico Valencia A, and 96 Australia were used as material belonging to Virginia, Valencia, and Spanish market types, 
respectively. Runner-type has a very long growing period and some problems with fully maturity in this region (Onemli, 1990), thus, it was not included in this study. Some comparative characters of Virginia, Spanish, and Valencia genotypes are presented in Table 1. Virginia has large seeds and pods, long growth period, spreading growth habit, no floral axes on main stem, alternating pairs of floral and reproductive axes on branches. Valencia usually has three or more small kernels per pod and covered in a red skin, and earliness for pod maturity, floral axes on main stem, alternating pairs of floral and vegetative axes on branches, little branched, curved branches. Spanish has smaller kernels covered with cream skin, floral axes on main stem, alternating pairs of floral and vegetative axes on branches, more branched, upright branches (Onemli, 1990; 1995; Tillman and Stalker, 2009).

\section{Experimental site and management}

Experiments were conducted at a farmer field in Kesan ( $40^{\circ} 51^{\prime}$ N, $26^{\circ} 38^{\prime}$ E, $185 \mathrm{~m}$ a.s.1.), Turkey, on a silty clay loam series in 2008, 2009, and 2010. Planting dates were in the first week of May for all years. The experimental design was a randomized complete block with three replicates for every year. Peanut was sown with a 0.7 $\mathrm{m}$ spacing between rows and $0.3 \mathrm{~m}$ spacing between plants in a row. Soil fertility was adjusted to $60 \mathrm{~kg} \mathrm{P}$ $\mathrm{ha}^{-1}$. Genotypes were harvested separately at $85 \%$ pods maturity according to shell out method. Some climatic data during peanut growth seasons in $3 \mathrm{yr}$ are given in Table 2. There were significant differences for rainfall, humidity, and temperature values especially during pod development of peanut amongst years.

\section{Seed oil and fatty acids analysis}

Seed oil and fatty acid analysis were conducted at the laboratory of Trakya Birlik, a Turkish Agricultural Cooperative. Seed oil content was determined with a pulsed NMR instrument (Bruker Minispec-Bruker Analytische Messtechnik, Karlsruhe, Germany). Oil contents are expressed as a percentage of dry seed weight (Warnsely, 1998).

Gas chromatography (GC) of fatty acid methyl esters (FAME) was performed with an Agilent $6890 \mathrm{~N}$ gas chromatography equipped with a flame ionization detector (FID). Analyses were conducted on an Agilent capillary column with column with $100 \mathrm{~m} \times 0.25 \mathrm{~mm}$ i.d., $0.2 \mu \mathrm{m}$ according to ISO 5508 (Ackman, 2002). The column temperature was programmed from 120 to $230{ }^{\circ} \mathrm{C}$; and injector and detector temperature set at $250{ }^{\circ} \mathrm{C}$ using helium, air, and hydrogen. Thirteen fatty acids were identified as percentage of total fatty acids These fatty acids were palmitic (C16:0), palmitoleic (C16:1), margaric (C17:0), heptadecanoic (C17:1), stearic (C18:0), oleic (C18:1), linoleic (C18:2), linolenic (C18:3), arachidic (C20:0), eicosanoic (C20:1), behenic (C22:0), erucic (C22:1), and lignoceric (C24:0).

\section{Statistical analysis}

Statistical analyses were conducted by using standard procedures using variety and year factors. The least significant difference (LSD) at 5\% probability was used to compare factors. Collected data were analyzed using the SAS statistical computer package (SAS Institute, 1997).

Table 1. Some comparative characters of Virginia, Spanish, and Valencia genotypes.

\begin{tabular}{|c|c|c|c|}
\hline Characters & Virginia (NC-7) & Valencia (New Mexico Valencia A) & Spanish (96 Australia) \\
\hline Growth period & long (175 d) & short (120 d) & medium (150 d) \\
\hline Growth habit & spreading & bunch & bunch \\
\hline Pod size & medium to large & medium to long & very small \\
\hline Seed per pod & usually 2 , occasionally 3 & usually 3-4 & usually 2 \\
\hline Shell thickness & thick & thick & thin \\
\hline Testa color & light brown & red & cream \\
\hline Seed size & medium to large & small to medium & small \\
\hline Seed dormancy & moderately present & little & little \\
\hline Branching & moderate to profuse & sparse to moderate & more-upright branches \\
\hline Flowering pattern & alternate & sequential & sequential \\
\hline Lateral branches & longer than stem & shorter than stem & shorter than main stem \\
\hline
\end{tabular}

Table 2. Some climatic data during peanut growth season in $3 \mathrm{yr}$.

\begin{tabular}{|c|c|c|c|c|c|c|c|c|c|c|c|c|c|c|c|c|c|c|}
\hline & & & & & & & & & & \multicolumn{9}{|c|}{ Temperature } \\
\hline & \multicolumn{3}{|c|}{ Rainfall } & \multicolumn{3}{|c|}{ Rainy day number } & \multicolumn{3}{|c|}{ Relative humidity } & \multicolumn{3}{|c|}{ Means } & \multicolumn{3}{|c|}{ Maximum } & \multicolumn{3}{|c|}{ Minimum } \\
\hline & 2008 & 2009 & 2010 & 2008 & 2009 & 2010 & 2008 & 2009 & 2010 & 2008 & 2009 & 2010 & 2008 & 2009 & 2010 & 2008 & 2009 & 2010 \\
\hline & 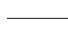 & $\mathrm{mm}$ & - & 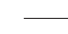 & d & - & 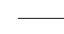 & $-\%$ & - & & & & & ${ }^{\circ} \mathrm{C}$ & 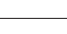 & & & \\
\hline May & 33.4 & 27.7 & 16.0 & 10 & 8 & 9 & 62.7 & 66.1 & 68.6 & 18.0 & 19.1 & 18.1 & 35.1 & 32.1 & 33.6 & 5.0 & 7.5 & 3.3 \\
\hline June & 45.7 & 25.9 & 30.8 & 8 & 7 & 12 & 62.1 & 62.5 & 72.3 & 23.3 & 22.6 & 22.5 & 36.7 & 36.4 & 38.7 & 8.7 & 9.3 & 12.0 \\
\hline July & 34.0 & 89.4 & 72.3 & 4 & 5 & 8 & 51.9 & 55.3 & 66.4 & 25.2 & 24.5 & 24.7 & 37.3 & 39.7 & 35.5 & 14.1 & 15.4 & 14.6 \\
\hline August & 8.1 & 17.0 & 0 & 3 & 1 & 0 & 49.2 & 51.9 & 56.9 & 26.3 & 25.0 & 28.1 & 38.6 & 37.0 & 39.6 & 15.7 & 14.2 & 15.8 \\
\hline Sept. & 71.6 & 74.1 & 31.4 & 8 & 6 & 4 & 62.3 & 67.7 & 64.8 & 19.6 & 19.9 & 21.2 & 35.4 & 36.9 & 33.8 & 7.0 & 6.6 & 9.0 \\
\hline October & 17.0 & 112.6 & 68.5 & 4 & 16 & 18 & 72.6 & 82.3 & 82.1 & 14.9 & 15.1 & 13.0 & 26.5 & 28.9 & 23.8 & 3.5 & 2.9 & -0.7 \\
\hline
\end{tabular}




\section{RESULTS AND DISCUSSION}

Variations of botanical variety and year were highly significant for all the parameters. Interaction varieties $x$ years were also found to be statistically significant for oil and all the fatty acids studied (Table 3 ).

\section{Varietal effects}

Oil content in different peanut market types exhibited significant differences (Table 4). The maximum oil content (51.993\%) was found in Virginia genotype (NC-7), while Valencia type (New Mexico Valencia A) accumulated the minimum oil content (47.197\%).

Fatty acid composition of peanut seed oils has been reported to be influenced by varietal effects, and Virginia cultivars, which belong to subspecies hypogaea, had higher oil content than Spanish and Valencia market types, which belong to subspecies fastigiata (Onemli, 1990; Savage and Keenan, 1994; Onemli, 1995; Asibuo et al., 2008; James Yaw et al., 2008). Important factors

Table 3. ANOVA of oil and fatty acid contents in peanut with variety, year, and interaction variety $\times$ year.

\begin{tabular}{|c|c|c|c|c|}
\hline \multirow[b]{2}{*}{ Oil and fatty acids } & \multicolumn{4}{|c|}{ Mean square } \\
\hline & Variety & Year & Variety $\times$ year & $\mathrm{CV}$ \\
\hline Oil content & $57.955^{* *}$ & $64.957^{* *}$ & $5.311^{* *}$ & 0.611 \\
\hline Palmitic (C16:0) & $0.292^{* *}$ & $1.338^{* *}$ & $4.246^{* *}$ & 0.637 \\
\hline Palmitoleic (C16:1) & $0.246^{* *}$ & $0.232^{* *}$ & $0.217^{* *}$ & 1.721 \\
\hline Margaric (C17:0) & $0.002^{* *}$ & $0.003^{* * *}$ & $0.001^{* * *}$ & 8.118 \\
\hline Heptadecanoic (C17:1) & $0.001 * *$ & $0.002^{* *}$ & $0.005^{* *}$ & 9.702 \\
\hline Stearic (C18:0) & $0.484^{* *}$ & $0.097^{* *}$ & $1.113^{* * *}$ & 0.854 \\
\hline Oleic $(\mathrm{C} 18: 1)$ & $109.528^{* *}$ & $35.257^{* *}$ & $78.155^{* *}$ & 0.096 \\
\hline Linoleic (C18:2) & $78.544^{* *}$ & $17.743^{* *}$ & $29.130^{* * *}$ & 0.106 \\
\hline Linolenic (C18:3) & $0.001^{* *}$ & $0.001^{* *}$ & $0.001^{* *}$ & 3.388 \\
\hline Arachidic (C20:0) & $0.045^{* *}$ & $0.061^{* * *}$ & $0.086^{* *}$ & 0.408 \\
\hline Eicosanoic (C20:1) & $0.035^{* *}$ & $0.086^{* *}$ & $0.123^{* *}$ & 0.273 \\
\hline Behenic (C22:0) & $0.232^{* *}$ & $1.205^{* *}$ & $0.693^{* *}$ & 0.747 \\
\hline Erucic (C22:1) & $0.003^{* *}$ & $0.004^{* *}$ & $0.005^{* *}$ & 4.159 \\
\hline Lignoceric (C24:0) & $1.479^{* *}$ & $0.480^{* * *}$ & $0.814^{* *}$ & 0.239 \\
\hline
\end{tabular}

${ }^{* *}$ Significant differences are shown at $\mathrm{P}<0.01$ based on ANOVA.

$\mathrm{CV}$ : The coefficient of variation, which is used to describe the amount of variation for oil and fatty acids content in the variety, year, and interaction variety $\times$ year.

Table 4. Variations in oil content and fatty acids (\%) in differing peanut groups.

\begin{tabular}{lrrrr}
\hline & \multicolumn{4}{c}{ Variety } \\
\cline { 2 - 5 } Oil content and & Virginia & Valencia & Spanish & LSD \\
fatty acids & $51.993 \mathrm{a}$ & $47.197 \mathrm{c}$ & $48.159 \mathrm{~b}$ & 0.300 \\
\hline Oil content & $11.080 \mathrm{~b}$ & $11.371 \mathrm{a}$ & $11.409 \mathrm{a}$ & 0.072 \\
Palmitic $(\mathrm{C} 16: 0)$ & $0.389 \mathrm{a}$ & $0.095 \mathrm{c}$ & $0.111 \mathrm{~b}$ & 0.003 \\
Palmitoleic $(\mathrm{C} 16: 1)$ & $0.084 \mathrm{a}$ & $0.062 \mathrm{~b}$ & $0.088 \mathrm{a}$ & 0.006 \\
Margaric $(\mathrm{C} 17: 0)$ & $0.046 \mathrm{a}$ & $0.028 \mathrm{~b}$ & $0.047 \mathrm{a}$ & 0.004 \\
Heptadecanoic $(\mathrm{C} 17: 1)$ & $2.884 \mathrm{c}$ & $3.346 \mathrm{a}$ & $3.159 \mathrm{~b}$ & 0.027 \\
Stearic $(\mathrm{C} 18: 0)$ & $45.694 \mathrm{a}$ & $38.851 \mathrm{c}$ & $43.450 \mathrm{~b}$ & 0.041 \\
Oleic (C18:1) & $32.802 \mathrm{c}$ & $38.505 \mathrm{a}$ & $34.318 \mathrm{~b}$ & 0.037 \\
Linoleic $(\mathrm{C} 18: 2)$ & $0.063 \mathrm{a}$ & $0.059 \mathrm{~b}$ & $0.063 \mathrm{a}$ & 0.002 \\
Linolenic $(\mathrm{C} 18: 3)$ & $1.413 \mathrm{c}$ & $1.553 \mathrm{a}$ & $1.497 \mathrm{~b}$ & 0.006 \\
Arachidic $(\mathrm{C} 20: 0)$ & $1.173 \mathrm{a}$ & $1.097 \mathrm{~b}$ & $1.049 \mathrm{c}$ & 0.003 \\
Eicosanoic $(\mathrm{C} 20: 1)$ & $2.889 \mathrm{c}$ & $3.179 \mathrm{a}$ & $3.153 \mathrm{~b}$ & 0.023 \\
Behenic $(\mathrm{C} 22: 0)$ & $0.080 \mathrm{~b}$ & $0.107 \mathrm{a}$ & $0.072 \mathrm{c}$ & 0.004 \\
Erucic $(\mathrm{C} 22: 1)$ & $1.582 \mathrm{~b}$ & $1.627 \mathrm{a}$ & $0.903 \mathrm{c}$ & 0.003 \\
Lignoceric $(\mathrm{C} 24: 0)$ & & & \\
\hline
\end{tabular}

Means within a row followed by same small letters are not different according to LSD test $(\mathrm{P}<0.05)$. influencing fatty acid composition are the variety and genetics of the seed (Gecgel et al., 2007).

The highest percentage of palmitic acid was found in Valencia and Spanish genotypes. Valencia-type had also highest stearic acid. Cultivars for every botanical variety in this study were selected as normal oleic type from traditional genotypes. Oleic acid was within the range of 38.851-45.694\% obtained for three genotypes. Virginiatype gave the highest percentage of oleic acid while Valencia had the lowest value. This trend was reverse with respect to linoleic acid concentration. The highest percentage of linoleic acid (38.505\%) was observed in Valencia genotype, while the lowest content $(32.802 \%)$ was in Virginia. As the results of fatty acids with market type, Valencia had also the higher percentages of arachidic, behenic, and lignoceric acid than Virginia and Spanish. Bansal et al. (1993) reported that fatty acid contents are related to the growth habit. The previous studies indicate the presence of peanuts and its products in the diet reduces the risk of heart disease by $21 \%$ (O'Byrne et al., 1997).

\section{Year effects}

Table 5 includes the variations in oil content and fatty acids response to years. Mean of oil percentages of genotypes in 2010 was lower than 2008 and 2009. The highest percentages of palmitic acid and stearic acid were recorded in 2009 with $11.58 \%$ and $3.203 \%$, respectively. In 2010 , oleic acid percentage in peanut oil was the highest although this year gave the lowest linoleic acid. Oleic, linoleic and saturated fatty acids were significantly affected by climatic fluctuates in years. Higher means of temperature during seed development (especially August and September in Table 2) in 2010 according to other $2 \mathrm{yr}$ resulted in greater oleic contents. Inversely, the lower temperatures post anthesis in 2009 occurred higher linoleic and total of saturated fatty acids. Fatty acid composition of peanut seed oils has been reported to be influenced by climate effects (Howell, 2001; Pattee, 2005). The variation of fatty acid composition with

Table 5. Variations in oil content (\%) and fatty acids response to years.

\begin{tabular}{|c|c|c|c|c|}
\hline \multirow{2}{*}{$\begin{array}{l}\text { Oil content and } \\
\text { fatty acids }\end{array}$} & \multicolumn{3}{|c|}{ Years } & \multirow[b]{2}{*}{ LSD } \\
\hline & 2008 & 2009 & 2010 & \\
\hline Oil content & $50.813 a$ & $50.517 \mathrm{a}$ & $46.019 b$ & 0.300 \\
\hline Palmitic (C16:0) & $10.850 \mathrm{c}$ & $11.580 \mathrm{a}$ & $11.430 \mathrm{~b}$ & 0.072 \\
\hline Palmitoleic (C16:1) & $0.101 \mathrm{c}$ & $0.111 \mathrm{~b}$ & $0.384 a$ & 0.003 \\
\hline Margaric (C17:0) & $0.085 b$ & $0.057 \mathrm{c}$ & $0.092 \mathrm{a}$ & 0.006 \\
\hline Heptadecanoic (C17:1) & $0.056 \mathrm{a}$ & $0.028 \mathrm{c}$ & $0.037 \mathrm{~b}$ & 0.004 \\
\hline Stearic $(\mathrm{C} 18: 0)$ & $3.174 b$ & $3.203 \mathrm{a}$ & $3.011 \mathrm{c}$ & 0.027 \\
\hline Oleic (C18:1) & $41.657 b$ & $41.393 c$ & $44.946 \mathrm{a}$ & 0.041 \\
\hline Linoleic (C18:2) & $35.907 \mathrm{~b}$ & $36.127 \mathrm{a}$ & $33.592 \mathrm{c}$ & 0.037 \\
\hline Linolenic (C18:3) & $0.074 \mathrm{a}$ & $0.055 \mathrm{~b}$ & $0.055 \mathrm{~b}$ & 0.002 \\
\hline Arachidic (C20:0) & $1.551 \mathrm{a}$ & $1.518 \mathrm{~b}$ & $1.394 \mathrm{c}$ & 0.006 \\
\hline Eicosanoic (C20:1) & $1.212 \mathrm{a}$ & $1.020 \mathrm{c}$ & $1.086 \mathrm{~b}$ & 0.003 \\
\hline Behenic (C22:0) & $3.430 \mathrm{a}$ & $3.092 \mathrm{~b}$ & $2.699 \mathrm{c}$ & 0.023 \\
\hline Erucic (C22:1) & $0.086 \mathrm{~b}$ & $0.064 \mathrm{c}$ & $0.109 \mathrm{a}$ & 0.004 \\
\hline Lignoceric (C24:0) & $1.143 \mathrm{c}$ & $1.605 \mathrm{a}$ & $1.364 \mathrm{~b}$ & 0.003 \\
\hline
\end{tabular}

Means within a row followed by same small letters are not different according to LSD test $(\mathrm{P}<0.05)$. 
climatic conditions, particularly moisture and temperature during the growing season, was indicated by (Gecgel et al., 2007).

\section{Variety $\times$ year interaction effects}

Peanut composition is also influenced by interaction varietal type $\times$ year (Table 6 ). The accumulation of oil and fatty acids in differing market types exhibited significant variations depend on years. Oil contents of Virginia and Valencia type were highest in 2008. Oil percentages of Spanish-type in 2008 and 2009 were statistically in the same group. Gecgel et al. (2007) reported that climatic factors during growing season, maturity, variety, and location influence oil concentration. It was observed different effects of years in oleic and linoleic acid composition according to peanut types. The highest oleic acid percentages were observed for Virginia in 2008 and for Valencia and Spanish in 2010. Virginia, Valencia, and Spanish had their greatest linoleic contents in 2010, 2008, and 2009, respectively. The highest palmitic contents were recorded for Virginia and Valencia in 2010, while Spanish gave the highest value in 2009. The highest stearic percentages were recorded in 2010 for Virginia, and in 2009 for Valencia and Spanish. Although Valencia and Spanish gave the highest behenic and arachidic acid percentages in 2008, it was in 2010 for Virginia. The similar effects of interaction variety $\times$ environment have been reported in Virginia and Spanish types by Bansal et al. (1993), in Runner-type by Branch et al. (1990) and Grosso et al. (1994), in only Spanish-type by Anderson et al. (1998), and with different breeding lines by Isleib et al. (2008). Market types have different growth period. The order of maturity of these market types from earliness to late is Valencia, Spanish, and Virginia (Onemli, 1990; 1995; Tillman and Stalker, 2009). They were exposed in this study differing climate fluctuates such as temperature during seed development in every year, thus the significant differences for oil content and fatty acids were exhibited in years by different market types.

\section{Correlations among oil fatty acids}

No significant correlation was observed for oil content with fatty acid percentages of peanut oil (Table 7). Palmitic acid was correlated positively with stearic, linoleic, arachidic, and behenic acids, and negatively with margaric, heptadecanoic, oleic, linolenic and eicosanoic acids. Percentage of stearic acid was shown to be correlated positively with linoleic, arachidic and behenic acids, and negatively with oleic and eicosanoic acids.

The highest negative correlation was noted for

Table 6. Variations in oil content and fatty acids (\%) of different peanut groups in $3 \mathrm{yr}$.

\begin{tabular}{|c|c|c|c|c|c|c|c|c|c|c|c|c|}
\hline \multirow{2}{*}{$\begin{array}{l}\text { Oil and fatty } \\
\text { acids }\end{array}$} & \multicolumn{4}{|c|}{ Virginia } & \multicolumn{4}{|c|}{ Valencia } & \multicolumn{4}{|c|}{ Spanish } \\
\hline & 2008 & 2009 & 2010 & LSD & 2008 & 2009 & 2010 & LSD & 2008 & 2009 & 2010 & LSD \\
\hline Oil content & $54.61 \mathrm{a}^{*}$ & $53.52 b$ & $47.85 \mathrm{c}$ & 0.19 & $48.25 \mathrm{a}$ & $47.60 \mathrm{~b}$ & $45.72 c$ & 0.32 & $49.58 \mathrm{a}$ & $50.41 \mathrm{a}$ & $44.49 \mathrm{~b}$ & 1.23 \\
\hline Palmitic & $10.12 \mathrm{c}$ & $10.82 b$ & $12.30 \mathrm{a}$ & 0.19 & $10.74 \mathrm{c}$ & $11.39 \mathrm{~b}$ & $11.98 \mathrm{a}$ & 0.12 & $11.69 \mathrm{~b}$ & $12.53 \mathrm{a}$ & $10.01 \mathrm{c}$ & 0.19 \\
\hline Palmitoleic & $0.12 b$ & $0.12 b$ & $0.93 \mathrm{a}$ & 0.01 & $0.09 \mathrm{~b}$ & $0.12 \mathrm{a}$ & $0.08 \mathrm{~b}$ & 0.01 & $0.10 \mathrm{~b}$ & $0.01 \mathrm{~b}$ & $0.14 \mathrm{a}$ & 0.01 \\
\hline Margaric & $0.10 \mathrm{a}$ & $0.06 \mathrm{~b}$ & $0.10 \mathrm{a}$ & 0.02 & $0.07 \mathrm{a}$ & $0.06 \mathrm{~b}$ & $0.06 \mathrm{~b}$ & 0.01 & $0.08 b$ & $0.06 \mathrm{c}$ & $0.12 \mathrm{a}$ & 0.01 \\
\hline Heptadecanoic & $0.10 \mathrm{a}$ & $0.04 \mathrm{~b}$ & $0.01 \mathrm{c}$ & 0.02 & $0.03 \mathrm{a}$ & $0.02 b$ & $0.03 b$ & 0.01 & $0.04 \mathrm{~b}$ & $0.02 \mathrm{c}$ & $0.08 \mathrm{a}$ & 0.01 \\
\hline Stearic & $2.79 \mathrm{~b}$ & $2.38 \mathrm{c}$ & $3.48 \mathrm{a}$ & 0.09 & $3.44 \mathrm{~b}$ & $3.50 \mathrm{a}$ & $3.10 \mathrm{c}$ & 0.05 & $3.29 \mathrm{~b}$ & $3.73 \mathrm{a}$ & $2.46 \mathrm{c}$ & 0.06 \\
\hline Oleic & $47.46 \mathrm{a}$ & $46.73 b$ & $42.89 \mathrm{c}$ & 0.05 & $37.88 \mathrm{c}$ & $38.87 \mathrm{~b}$ & $39.80 \mathrm{a}$ & 0.16 & $3.96 \mathrm{~b}$ & $38.58 \mathrm{c}$ & $52.14 \mathrm{a}$ & 0.04 \\
\hline Linoleic & $31.87 \mathrm{c}$ & $32.31 \mathrm{~b}$ & $34.23 \mathrm{a}$ & 0.04 & $39.46 \mathrm{a}$ & $38.35 b$ & $37.72 \mathrm{c}$ & 0.11 & $36.40 \mathrm{~b}$ & $37.72 \mathrm{a}$ & $28.83 \mathrm{c}$ & 0.11 \\
\hline Linolenic & $0.08 \mathrm{a}$ & $0.06 \mathrm{~b}$ & $0.05 \mathrm{c}$ & 0.01 & 0.06 & 0.06 & 0.06 & ns & $0.09 \mathrm{a}$ & $0.04 \mathrm{c}$ & $0.06 \mathrm{~b}$ & 0.01 \\
\hline Arachidic & $1.38 \mathrm{~b}$ & $1.33 \mathrm{c}$ & $1.53 \mathrm{a}$ & 0.01 & $1.63 \mathrm{a}$ & $1.60 \mathrm{~b}$ & $1.43 \mathrm{c}$ & 0.02 & $1.64 \mathrm{a}$ & $1.63 \mathrm{~b}$ & $1.22 \mathrm{c}$ & 0.01 \\
\hline Eicosanoic & $1.32 \mathrm{a}$ & $1.29 \mathrm{~b}$ & $0.91 \mathrm{c}$ & 0.01 & $1.13 \mathrm{~b}$ & $0.94 \mathrm{c}$ & $1.23 \mathrm{a}$ & 0.01 & $1.20 \mathrm{a}$ & $0.83 \mathrm{c}$ & $1.12 \mathrm{~b}$ & 0.01 \\
\hline Behenic & $2.79 \mathrm{~b}$ & $2.90 \mathrm{a}$ & $2.98 \mathrm{a}$ & 0.08 & $3.49 \mathrm{a}$ & $3.21 \mathrm{~b}$ & $2.84 \mathrm{c}$ & 0.04 & $4.01 \mathrm{a}$ & $3.17 \mathrm{~b}$ & $2.28 \mathrm{c}$ & 0.04 \\
\hline Erucic & $0.09 \mathrm{a}$ & $0.08 \mathrm{a}$ & $0.07 \mathrm{~b}$ & 0.01 & $0.08 \mathrm{~b}$ & $0.01 \mathrm{c}$ & $0.18 \mathrm{a}$ & 0.01 & $0.09 \mathrm{a}$ & $0.05 \mathrm{c}$ & $0.08 \mathrm{~b}$ & 0.01 \\
\hline Lignoceric & $1.69 \mathrm{~b}$ & $1.78 \mathrm{a}$ & $1.27 \mathrm{c}$ & 0.01 & $1.74 \mathrm{a}$ & $1.64 \mathrm{~b}$ & $1.50 \mathrm{c}$ & 0.01 & $0.01 \mathrm{c}$ & $1.39 \mathrm{a}$ & $1.32 \mathrm{~b}$ & 0.01 \\
\hline
\end{tabular}

"Means among years within a variety followed by same small letters are not significantly different according to LSD test $(\mathrm{P}<0.05)$.

Table 7. Correlation coefficients of fatty acids and oil content in peanut.

\begin{tabular}{|c|c|c|c|c|c|c|c|c|c|c|c|c|c|}
\hline & C16:0 & C16:1 & C17:0 & C17:1 & C18:0 & C18:1 & C18:2 & C18:3 & C20:0 & C20:1 & C22:0 & C22:1 & $\mathrm{C} 24: 0$ \\
\hline Oil & -0.163 & -0.139 & -0.190 & 0.253 & -0.181 & 0.097 & -0.140 & 0.327 & 0.015 & 0.352 & 0.174 & -0.248 & 0.147 \\
\hline C16:0 & & 0.369 & $-0.498^{*}$ & $-0.840^{* *}$ & $0.734^{* *}$ & $-0.690^{* *}$ & $0.596^{* *}$ & $-0.453^{*}$ & $0.633^{* *}$ & $-0.623^{* *}$ & $0.407^{*}$ & 0.024 & -0.304 \\
\hline C16:1 & & & 0.310 & $-0.437^{*}$ & 0.229 & 0.073 & 0.158 & -0.296 & 0.051 & -0.412 & -0.113 & -0.225 & -0.061 \\
\hline C17:0 & & & & $0.558^{*}$ & -0.361 & $0.687^{* *}$ & $-0.706^{* *}$ & 0.245 & -0.472 & 0.131 & $-0.407^{*}$ & -0.134 & -0.207 \\
\hline C17:1 & & & & & $-0.666^{* *}$ & $0.712^{* *}$ & $-0.656^{* * *}$ & $0.468^{*}$ & $-0.638^{* *}$ & $0.593^{*}$ & $-0.455^{*}$ & 0.071 & 0.134 \\
\hline C18:0 & & & & & & $-0.860^{* *}$ & $0.816^{* *}$ & -0.322 & $0.915^{* *}$ & $-0.740^{* *}$ & $0.595^{*}$ & -0.255 & -0.199 \\
\hline C18:1 & & & & & & & $-0.985^{* *}$ & 0.159 & $-0.921^{* *}$ & $0.417^{*}$ & $-0.754^{* *}$ & -0.038 & 0.168 \\
\hline C18:2 & & & & & & & & -0.188 & $0.868^{* *}$ & -0.374 & $0.686^{* *}$ & 0.087 & -0.046 \\
\hline C18:3 & & & & & & & & & -0.029 & $0.679^{* *}$ & $0.405^{*}$ & 0.135 & $-0.519^{*}$ \\
\hline C20:0 & & & & & & & & & & $-0.515^{*}$ & $0.857^{* *}$ & -0.271 & -0.338 \\
\hline C20:1 & & & & & & & & & & & -0.103 & $0.565^{*}$ & 0.017 \\
\hline $\mathrm{C} 22: 0$ & & & & & & & & & & & & -0.161 & $-0.583^{*}$ \\
\hline C24:0 & & & & & & & & & & & & & 0.013 \\
\hline
\end{tabular}

Palmitic (C16:0), Palmitoleic (C16:1), Margaric (C17:0), Heptadecanoic (C17:1), Stearic (C18:0), Oleic (C18:1), Linoleic (C18:2), Linolenic (C18:3), Arachidic (C20:0), Eicosanoic (C20:1), Behenic (C22:0), Erucic (C22:1), Lignoceric (C24:0).

"Significant at $\mathrm{P}<0.05$ and ${ }^{* *}$ Significant at $\mathrm{P}<0.01$. 
oleic and linoleic acids (r: -0.985). Oleic acid was also negatively correlated with arachidic and behenic acids. Positive relationships occurred between linoleic acid and arachidic, and behenic acids. Arachidic acid was highly correlated with behenic acid.

Similar correlations have been reported in previous studies (Dwivedi et al., 1993; Hammond et al., 1997; Anderson et al., 1998). Mercel et al. (1990) has also suggested that fatty acid composition should not affect the oil content of seed.

\section{CONCLUSIONS}

The significant differences exhibited by different cultivars in this study during $3 \mathrm{yr}$ for oil content and fatty acids could be attributed to the genetic make-up of a particular cultivar, its place of the environmental to reach high oil quality. Knowing better combination effects of climatic fluctuations and botanical types on fatty acid composition would be useful in designing management practices to obtain a specific oil quality and improving predictions of crop models.

\section{ACKNOWLEDGEMENTS}

The author is grateful to the Factory of Trakya Birlik for GC analyses of the oil samples.

\section{Impacto del cambio climático en la composición de} ácidos grasos del aceite de maní (Arachis hypogaea L.) de tres clases comerciales. El maní (Arachis hypogaea L.) es uno de los cultivos oleaginosos más importantes del mundo. La composición de los ácidos grasos juega un rol importante en la calidad del aceite. Los experimentos se llevaron a cabo en los años 2008, 2009, y 2010, para determinar la variación en la composición de ácidos grasos de tres clases comerciales de maní (Virginia, Valencia y Spanish) con contenido normal de ácido oleico. La variación entre variedades botánicas, año, y su interacción fueron altamente significativas para el contenido de aceite y los 13 ácidos grasos estudiados. El contenido de aceite en las diferentes clases comerciales exhibió marcadas diferencias. El máximo contenido de aceite $(51.993 \%)$ se obtuvo en la clase Virginia (NC-7), mientras que en la clase Valencia (New Mexico Valencia A) se obtuvo el menor contenido de aceite (47.197\%). La clase Virginia también obtuvo el valor más alto de ácido oleico. Temperaturas más altas durante el desarrollo de la semilla en el 2010 resultaron en contenidos más altos de ácido oleico que en el 2008 y el 2009, mientras que temperaturas más bajas post antesis en el 2009 condujeron a un contenido más alto de ácido linoleico. El efecto del año en la composición de los ácidos grasos fue distinto dependiendo de la clase comercial de maní. El contenido más alto de ácido linoleico para las clases Virginia, Valencia y Spanish se observó en el 2010, 2008, y 2009, respectivamente. La correlación negativa menor se observó entre el contenido de los ácidos oleico y linoleico (r: -0.985). El ácido oleico también se correlacionó negativamente con los ácidos araquídico y behénico.

Palabras clave: Arachis hypogaea subsp. fastigiata, temperatura, correlación.

\section{LITERATURE CITED}

Ackman, R.G. 2002. The gas chromatograph in practical analyses of common and uncommon fatty acids for the 21 st century. Analytica Chimica Acta 465:175-192.

Anderson, P.C., K. Hill, D.W. Gorbet, and B.V. Brodbeck. 1998. Fatty acid and amino acid profiles of selected peanut cultivars and breeding lines. Journal of Food Composition and Analysis 11:100111

Aruna, R., and S.N. Nigam. 2009. Inheritance of fatty acid content and related quality traits in groundnut (Arachis hypogaea L.) Oilseed Research 26:10-17.

Asibuo, J.Y., R. Akromah, H.K. Adu-Dapaah, and O. Safo-Kantanka. 2008. Evaluation of nutritional quality of groundnut (Arachis hypogaea L.) from Ghana. African Journal of Food Agriculture Nutrition and Development 8:133-150.

Bansal, U.K., D.R. Satija, and K.L. Ahuja. 1993. Oil composition of diverse groundnut (Arachis hypogaea L.) genotypes in relation to different environments. Journal of the Science of Food and Agriculture 63:17-19.

Berry, S.K. 1982. Fatty acid composition of 16 groundnut (Arachis hypogaea L.) cultivars grown under Malaysian conditions. Pertanika 5:20-24.

Branch, W.D., T. Nakayama, and M.S. Chinnan. 1990. Fatty acid variation among U.S. Runner-type peanut cultivars. Journal of the American Oil Chemists' Society 67:591-596.

Dwivedi, S.L., S.N. Nigam, R. Jambunathan, K.L. Sharawat, G.V.S. Nagabhushanam, and K. Raghunath. 1993. Effect of genotypes and environment on oil content and oil quality parameters and their correlation in peanut (Arachis hypogaea L.) Peanut Science 20:84-89.

Dwivedi, S.L., S.N. Nigam, R.C. Nagaswara Rao, U. Singh, and K.V.S. Rao. 1996. Effect of drought on oil, fatty acids and protein contents of groundnut (Arachis hypogaea L.) Field Crops Research 48:125-133.

Gecgel, U., M. Demirci, E. Esendal, and M. Tasan. 2007. Fatty acid composition of the oil from developing seeds of different varieties of safflower (Carthamus tinctorius L.) Journal of the American Oil Chemists' Society 84:47-54.

Golombek, S.D., A. Sultana, and C. Johansen. 2001. Effect of separate pod and root zone temperatures on yield and seed composition of three Spanish cultivars of groundnut (Arachis hypogaea L.) Journal of the Science of Food and Agriculture 81:1326-1333

Grosso, N.R., A. Lamarque, D.M. Maestri, J.A. Zygadlo, and C.A. Guzman. 1994. Fatty acid variation of Runner peanut (Arachis hypogaea L.) among geographic localities from Cordoba (Argentina). Journal of the American Oil Chemists' Society 71:541-542.

Hammond, E.G., D. Duvick, T. Wang, H. Dodo, and R.N. Pittman. 1997. Survey of the fatty acid composition of peanut (Arachis hypogaea) germplasm and characterization of their epoxy and eicosenoic acids. Journal of the American Oil Chemists' Society 74:235-1239.

Hassan, F.U., A. Manaf, and M. Ejaz. 2005. Determinants of oil and fatty acid accumulation in peanut. International Journal of Agriculture and Biology 7:895-899.

Hinds, M.J. 1995. Fatty acid composition of Caribbean-grown peanuts (Arachis hypogaea L.) at three maturity stages. Food Chemistry 53:7-14. 
Howell, B.D. 2001. Genotype evaluations for productivity and quality of peanut in West Texas. Thesis MSc. Texas Tech University, Crop Science, Lubbock, Texas, USA.

Isleib, T.G., B.L. Tillman, H.E. Pattee, T.H. Sanders, K.W. Hendrix, and L.O. Dean. 2008. Genotype-by-environment interactions for seed composition traits of breeding lines in the Uniform Peanut Performance Test. Peanut Science 35:130-138.

James Yaw, A., A. Richard, S.K. Osei, A.D. Kofi, O.D. Seth, and A. Adelaide. 2008. Chemical composition of groundnut, Arachis hypogaea (L.) landraces. African Journal of Biotechnology 7:2203-2208

Mercel, L.C., J.C. Wynne, and T. Young. 1990. Inheritance of fatty acid content in peanut oil. Peanut Science 17:17-21.

Nadaf, H.L., S.B. Kaveri, K. Madhusudan, and B.N. Motagi. 2009. Induced genetic variability for yield and yield components in peanut (Arachis hypogaea L.) p. 346-348. In Q.Y. Shu (ed.) Induced plant mutations in the genomics era. FAO, Rome, Italy.

O’Byrne, D.J., D.A. Knauft, and R.B. Shireman. 1997. Low fatmonounsaturated rich diets containing high-oleic peanuts improve serum lipoprotein profiles. Lipids 32:687-695.

Onemli, F. 1990. A research on some agronomical characters of peanut cultivars. Thesis MSc. University of Trakya, Institute of Natural Sciences, Department of Field Crops, Edirne, Turkey.
Onemli, F. 1995. The improving early maturing peanut cultivars by progeny controlled single plant selection method. Thesis $\mathrm{PhD}$. University of Trakya, Institute of Natural Sciences, Department of Field Crops, Edirne, Turkey.

Pattee, H.E. 2005. Peanut oil. p. 431-463. In F. Shahidi (ed.) Bailey's industrial oil and fat products. $6^{\text {th }}$ ed. John Wiley \& Sons, Hoboken, New Jersey, USA.

Reddy, T.Y., V.R. Reddy, and V. Anbumozhi. 2003. Physiological responses of groundnut (Arachis hypogea L.) to drought stress and its amelioration. Plant Growth Regulation 41:75-88.

Savage, G.P., and J.I. Keenan. 1994. The composition and nutritive value of groundnut kernels. p. 173-213. In J. Smartt (ed.) The groundnut crop: A scientific basis for improvement. Chapman and Hall, London, UK.

SAS Institute. 1997. The SAS System for Windows. Release 9.1 SAS Institute, Cary, North Carolina, USA.

Stalker, H.T. 1997. Peanut (Arachis hypogaea L.) Field Crops Research 53:205-217.

Tillman, B.L., and H.T. Stalker. 2009. Peanut. p. 287-316. In Vollmann, J., and I. Rajcan (eds.) Handbook of plant breeding-oil crops. Springer, New York, USA.

Warnsely, J. 1998. Simultaneous determination of oil and moisture in seed by NMR. Lipid Technology 10:6. 